AÜIFD Cilt XLIII (2002) Sayt 2 s. 151-168

\title{
"Müteşabih Ayetler" Kavramı Hakkında Tarihî ve Semantik Bir İnceleme
}

\author{
Enver APA \\ Dr., \\ enverarpa@hotmail.com
}

The Qur'an is the book of God sent to guide mankind through the right path. Applying the Qur'an correctly depends on the appropriate understanding of the reader. One of the main problems of the reader is understanding "Mütaşabih verses" theory. While this theory is to help in the understanding of the Holy Quran, it has rather turned into hinderance. In this 'article' the semantic and historic investigation of concept "Mütaşabih verses", what has been tried to explain and meant, has been researched and scrutinized. The opinions given and asserted for this purpose, has been studied and evaluated one by one. As a result of these evaluations and studies, it has been tried to explain what the "Mütaşabih verses" are. Key Word: Muhkem, Müteşabih, Te'vil, Tefsir.

\section{Giriş}

Hayat, insanın belirli esaslar dahilinde sınandığı bir alandır. Allah (c.c) bu esasları tebliğ etmek maksadıyla zaman zaman elçilerini İlahî mesajı ile göndermiştir. Bu İlahî mesajın son halkası, Hz. Peygamber (s.a.v) vasıtasıyla gönderilen Kur'an`dır. Kur'an` in amacı bu alanın sınırlarını tespit etmektir. $O$ 
sadece bir ibadet veya dua kitabı değildir. Bilakis onun yüklendiği bir misyon vardır: İnsanları yanlı̧ yoldan kurtarıp doğru yola sevk etmek. Kur'an, bu misyonunu ilk muhatap nesilde hakkıyla yerine getirmiştir. İnsanlar onu okumuş, anlamış ve ona göre hayatlarını tanzim etmişlerdir.

Onunla direkt muhatap olan bu ilk neslin yok olmasıyla birlikte insanların ona yaklaşımı farklılaşmaya; Müslümanların coğrafî sınırları genişleyip sayıları arttıkça da buna paralel olarak toplumsal problemler çoğalmaya başlamıştır. Bu problemlerin doğurduğu çeşitli fırkalar, Kur'an` 1 kendi amaçları doğrultusunda yorumlamaya başlamış, yorumlanna tezat teşkil eden ayetleri ise genellikle müteşabih sayarak manasını Allah`a havale etmişlerdir. Böylece o, asıl olması gerekirken insanların kendi fikirlerine destek bulmak için başvurdukları bir kitap haline dönüşmüş̧ür.

Kur'an`in bu misyonu göz ardı edildikçe mesajının anlaşılması hususunda zorluklar belirmiş, âlimler onun daha iyi anlaşılması için çeşitli çabalar harcamışlardır. Zamanla Kur'an ilimleri veya tefsir ilimleri olarak adlandırılan bu ilimlerin en önemlilerinden biri muhkem-müteşabih konusudur. Muhkem-müteşabih sorunu, zamanla giderek Kur'an'ın tümüyle anlaşılıp anlaşılamayacağı noktasına doğru kaymıştır. Biz bu çalışmamızda, "Kur'an tümüyle anlaşılabilir mi?" sorusuna cevap arayacağız.

Kanaatimizce muhkem-müteşabih sorunu, Kur'an` in gerçek veçhesinin anlaşılmasında bir engel teşkil etmektedir. Insanlar onun muhkemini ve müteşabihini tespit etmeye çalışırken asıl mesajdan iyice uzaklaşmışlardır. Bu konunun araştırılıp neticeye vardırılmasının Kur'an`ı anlamada yardımcı olacağına inanıyoruz.

\section{Muhkem ve Müteşabih Kavramlarının Lügat Manaları}

\section{Muhkem in Lügat Manası}

Muhkem, "Ha-ke-me" kökünden olup, menetmek, geri çevirmek manasına gelmektedir. Meşhur Şair Cerir, bir şiirinde şöyle demektedir: ${ }^{1}$

\section{E Benî Hanîfete ahkimû sufehâekum \\ Innî ehafu aleykum en eğdaba}

"Ey Hanife Oğulları! Sefihlerinizi benden uzak tutun, bana saldırmalarını engelleyin. Zira size gazab duyacağımdan korkuyorum."

İnsanları zulümden men ettiği için, hâkim`e insanlar arasında hâkim denilmiştir. Meşhur dilci Esmaî, hükümet kelimesinin bu manadan

1. Bkz. İbn Manzur, Lisanül-Arab; 1956, Beyrut, 12/144; Cevherî, es-Sthah tâcü'l-lügeti ve sıhahü "l-Arabiyye. Ahmed Abdülğgafur neşri, Mısır, 5/1902. 
geldiğini söylemektedir. ${ }^{2}$ Eksiklikleri yok etme anlaminda "Ehkeme'l-emre" yani işi sağlamlaştırdı, olgunlaştırdı; tecrübeli insana "Kad ahkemethu'ttecarib" tecrübeler onu olgunlaştırdı denilir. ${ }^{3}$ Kur'an bu anlamda tümünü "muhkem" olarak isimlendirmiştir: "Kitabun uhkimet âyâtuhu"4 yani ayetleri; üslûbuyla, nazmıyla eksikliklerden arındırılmıştır. ${ }^{5}$

\section{Istılah Manası}

Muhkemin terim manası, lügat manası ile ilişkili olarak gelişmiştir. Ayetlere, kendisinde şüphe, kapalılık ve anlaşılmasına engel teşkil eden şeyler yok edilmiştir anlamında muhkem yani sağlam (şüphesiz) anlaşllır denmiştir. İbn Âşur:

"Âli Imrân suresindeki muhkem, istiâre yoluyla manası açık olana ttlak olunmuştur.

Çünkü delaleti kesin olan şeyde kasıt hususunda şuphe uyandiracak şeyler men edilmiştir" demektedir. ${ }^{6}$

Muhkemin "Delalet ettiği şey açık ve kolayca anlaşılan ayetler" olduğu hususunda âlimler ittifak halindedirler.?

Muhkem ve müteşabih kavramlarının birlikte ele alınmaları, muhkemin anlaşılamamasından değil, Kur'an`da bu iki kavramın, birbirinin karşıtı olarak kullanılmalarından kaynaklanmaktadır. Müteşabihten bahsedildiğinde doğal olarak onun karşıtı olarak verilen muhkem de söz konusu olmaktadır.

Biz de bundan dolayı bu incelememizde muhkemden ziyade müteşabih kavramı üzerinde duracağız.

\section{Müteşabihin Lügat Manası}

"Şe-be-he" kökünün bir türevi olan "müteşabih", benzemek, dengi olmak manasına gelir. Arapça'da: Bir şey başka bir şeye benzedi, onunla aynı hâle geldi demek için "İştebehe's-şey'u eş-şey'e" denilir. ${ }^{8}$ Dilimizde de "teşbihte hata yoktur" yani temsilde (benzetmede) hata yoktur şeklinde kullanılmaktadır. Buna göre "el-müteşabihat", "el-mütemasilat" yani benzerler anlamına gelir.

2. Bkz. Ibn Manzur, a.g.e., XII/141.

3. Muhkem kelimesinin manası için bkz.a.g.e., XII/144.

4. Hûd Suresi: $\mathrm{XI} / 1$.

5. el-Beydavî, Envaru't-tenzil ve esraru't-te'vil, Daru'l-Fikr baskısı, trh. 1.cild, 2.cüz, s. 4.

6. et Tahrir ve't-tenvir. Tunus, trh. III/154.

7. İleride alimlerin görựşlerini incelerken göreceğimiz gibi muhkem hakkında ileri sürưlen tüm görüşlerin ortak noktası muhkemin manasının anlaşılabileceği hususudur. Ibn Âşur da et-Tahrir ve't-tenvir isimli tefsirinde, bunu cumhura nisbet etmiştir. Bkz. III/156.

8. Bkz. Ibn Manzur, a.g.e., XIII/503. 
Kur'an, bu manada tümünü müteşabih olarak isimlendirmiştir: "Allahu nezzele ahsene'l-hadîsi kitâben müteşabihen"9 yani ayetleri; manalarının sthhati, sözlerinin belağati hususunda birbirinin benzeridir. ${ }^{10}$

\section{Müteşabih Ne Demektir?}

Kur'an` 1 , lügat manalarıyla tümünü muhkem veya müteşabih saymak mümkündür. Semantik yönden ortada olan bu açılığa rağmen bu konuda görüş aynlıklarının ortaya çıkmasının sebebi, bu iki kavramın Âli İmrân suresinde özel bir anlamda kullanılmalanıdır. Bu konunun esasını teşkil eden Âli İmrân suresi 7. ayetinde Cenabı Allah şöyle buyuruyor:

"Kitabı sana indiren O'dur. Onun bir kısım ayetleri muhkemdir ki, onlar kitabın aslını oluştururlar. Diğer bir kısmı ise müteşabihtir. Kalplerinde egrilik olanlar fitne çıkarmak ve te'vil etmek (istediklerine çekmek) için onun müteşabih ayetlerinin ardına düşerler.

Oysa onun te vilini Allah' tan ve ilimde rasih olanlardan başkası bilemez. ${ }^{11}$ Onlar: 'Ona

inandık, hepsi Rabbimizin katındandır' derler. Akıl sahiplerinden başkası düşünüp öğüt almaz."

Ayeti kerime daha önceki kullanımlarından farklı olarak, Kur'an`ın ayetlerini iki gruba ayırmaktadır: Muhkemat ve onun karşıtı olarak verilen müteşabihat. Muhkem olanlar, Kur'an` ın aslını; müteşabih olanlar ise manalanını kapalılı̆̆ı sebebiyle kalplerinde eğrilik olanların te` vil yoluyla fitne çıkarma gayelerine zemin oluşturmaktadır. Burada müteşabihatın ne olduğu hususunda bir müphemlik bulunmaktadır ve bu müphemlik büyük ihtilaflara sebebiyet vermiştir. Kimisi müteşabihin bilinebileceğini kabul ederken kimisi bunun bilgisini Allah`a havale etmiştir. Böylece vardıkları neticeler bu varsayımlarına uygun olmuştur.

Biz, burada, sorunun daha iyi anlaşılması amacıyla onun şimdiye kadar nasıl algılandığını tespit etmek üzere âlimlerin bu husustaki görüşlerini verip onları inceleyerek, isabetli ve isabetsiz taraflarını tespit etmeye, sonra bu husustaki tercihimizi ve gerekçelerini izah etmeye çalışacağız.

\section{Âlimlerin Görüşleri}

Âlimlerin bu konudaki görüşlerini şu maddeler altında toplayabiliriz:

1- Ibn Abbas, İbn Mesud, Katâde ve Süddî gibi sahabe ve tabiîlere nispet edilen bir görüşe göre müteşabih, Kur'an` da neshedilen ayetlerdir. ${ }^{12}$

9. Zümer suresi: XXXIX/23.

10. el-Beydavî, Envaru't-tenzil ve esraru't-te'vil, 1.cild, 2.cüz, s. 4.

11. Ayeti bu şekilde tercumc etmeyi uygun bulduk; bunun izahı ileride verilecektir.

12. Taberî, Camiu'l-beyan, 2.baskı, 1954, Mısır, 3/172 ; Ibn Teymiyye, Mecmuu'l-fetâva li şeyhi'l-İslam Ibn Teymiyye, Daru Âlemi'l-Kutub, Riyad, 1991, XVII/387; Ibn Âşur, etTahrir ve t-tenvir, III/15. 
Müteşabihi neshedilen ayetler şeklinde izah etmek, bilinmeyeni bir başka bilinmeyenle açıklamaya benzemektedir. Neshedilen ayetler konusu, müteşabih ayetler konusundan daha kapalı ve karmaşıktır. Ayette kastedilen müteşabihin mensuh ayetler olması mümkün değildir. Zira bu manayla hem kelimenin lügat manasından uzaklaşılmakta hem de ayetin siyakıyla münasebeti kesilmektedir. Özellikle de ayette bulunan vakfeyi ismi celal (Allah lafzı) üzerinde yapanlar için bu yorum tümüyle imkansız hale gelmektedir. Zira ilimde rasih olanların, mensuh ayetlerin manasını bilebilecekleri malumdur. Ileride değineceğimiz gibi kendilerine bu görüş nisbet edilenler ilimde rasih olanların müteşabihatı bildiklerini kabul etmektedirler. ${ }^{13}$

2- Yine İbn Abbas'a nisbet edilen bir görüşe göre ise müteşabih, bazı surelerin başında bulunan hurufu mukattaalardır. ${ }^{14}$

Bu da uzak bir görüştür. Çünkü bu harfler bir "kelam" değildir ki manası anlaşılmamış olsun. Kûfe ekolü dışındaki âlimler, onlan müstakil bir ayet olarak kabul etmemektedirler. ${ }^{15}$ Kanaatimiz odur ki bu harfler, eylemsel bir mesaj vermekten ziyade, muhatabın dikkatini çekmek için, tıpkı (hâ-zâ) da olduğu gibi birer tenbih edatı olarak kullanılmış ve muhataplarınca bu şekilde algılanmışlardır. Bu, Arapça'da bilinen bir üslûbdur. Cenabı Allah bu harflerle muhatabın dikkatini çekerek, onları gelecek olan emirler hakkında uyanık kılmayı dilemiştir. ${ }^{16}$ Selef âlimleri, onların bu fonksiyonunu bildikleri için, anlama hususunda herhangi bir zorluk çekmemiş ve herhangi bir gayret içerisinde olmamışlardır. Sahabe ve ilk dönem müfessirlerine ait tefsir kaynaklannda bu hususta fazla bir bilgi bulunmayışı bunu desteklemektedir. Kur'an'ın inişinin üzerinden zaman geçtikçe, ilk dönemlerde âşina olunan bu üslub unutulmaya başlanmış ve bu harflerin manası hakkında tartışmalar ortaya çıkmıştır. Bu yüzden daha sonraları müfessirlerin bu harfleri izah etmeye başladığını görüyoruz.

Ayrıca sadece bu harfleri müteşabih saymak Maide ayetinin nüzul sebebiyle de çelişmektedir. Bu konudaki rivayetlerden de anlaşılacağı gibi sadece bu harfler müteşabih olarak söz konusu edilemez.17 Müteşabih

13. Bkz. İbn Teymiyye, el-Fetâva, XVII/395, 17/418. Söz konusu kişilerin müteşabihi bildiklerine dair rivayetler için bkz. et-Taben̂, Camiu'l-beyan, III/18.

14. Ibn Teymiyye, el-Fetâva, XVII/420; Reşit Rıza, Tefsiru'l-Kur'ani'l-hakim (el-Menar), Menar Matbaası, Mısır, trh. III/192.

15. Bu konuda daha fazla bilgi için bkz. ez-Zemahşer̂, Mahmud b. Amr, el-Keş̧af an hakaiki't-tenz'il ve uyuni'l-akavil fi vucuhi't-te'vil, Daru'l-Fikr, 1. bask1, 1977, 1/106; elBeydavî, Envaru't-tenzil ve esraru't-te'vil, $1 / 46$.

16. Bu konuda geniş bilgi için bkz. Ibn Âşur, et-Tahrir ve't-tenvir, I/206-218.

17. İbn Teymiyye, el-Fetâva, XVII/421. 
ayetlerden kastın bu harfler olmadığının önemli bir gerekçesi de ileride işaret edeceğimiz gibi, kalplerinde hastalık olanların, bu harflere değil, manasının anlaşılmasında zorluk bulunan diğer ayetlere sarılmış olmalarıdır.

3- Muhkem, âlimlerin te`vilini bildikleri ayetler, müteşabih ise kıyamet saati gibi hiç kimsenin mahiyetini bilemeyeceği hususlardır. Bu görüş de Abdullah b. Cabir'e nisbet edilmiştir. ${ }^{18}$

Müteşabihatı Kıyamet' in saati, Dabbe' nin ortaya çıkması gibi olaylara has kılmak da kanaatimizce doğru bir yaklaşım değildir. Zira ne Kıyamet' in saati ne de Dabbe'nin ortaya çıkış zamanı, ayetlerin konusu değildir. Aksine ayet kıyametin bilinemeyeceğini söylüyor. Ayetin metninin anlaşılmasında bir müşkil bulunmamaktadır. Kimse 'Acaba Allah bu ayette neyi kastetti?' diye bir sorgulamaya girişmemiştir. Kıyametin ne zaman kopacağı, Dabbe'nin ne zaman zuhur edeceği gibi hususlar ayetin metnini aşan metin ötesi hususlardır. Allah metinde bu hususlan açığa çıkarmayı dilememiştir. ${ }^{19}$

4- Muhkem, aklın manasını kavrayabileceği, müteşabih ise namazın rekatları, orucun ramazan ayına tekabül etmesi gibi aklın kavrayamayacağı hususlardır. Suyutî, bu göriişü Maverdî’ye dayandırmıştır. ${ }^{20}$

Aklın manasını kavrayamadığı hususlara misal olarak verilen namazın rekat sayısı, orucun Ramazan ayına tekabülü gibi hususlann da ayetlerin metninin anlaşılmasıyla bir ilgisi yoktur. Ayetler bunlardan hiç bahsetmemektedir.

5- Mücahid'e nispet edilen bir görüşte ise muhkem; helal, haram, hudutlar, vb. şeylerden bahseden ayetler, müteşabih ise bunların dışındakilerdir. ${ }^{21}$

6- İkrime ve Katâde gibi tabiîlere nispet edilen bir görüşte muhkem, amelî konuları içeren ayetler; müteşabih ise inanılan fakat amel edilmeyen ayetlerdir. ${ }^{22}$

Kur'an'da bu gibi hallerden bahseden ayetlerin sayısı 500 civarındadır. Diğer bölüm ise Allah' in sıfatlarından, cennet, cehennem, kainat, vb. hususlardan bahsetmektedir. Kur'an`ın aslı olarak belirtilen muhkemi 500 dolayında ayetle sınırlayıp, müteşabihi de Allah tan başka kimse bilemez dersek, Kur'an`ın büyük bölümünün anlaşılamayacağı sonucuna varırız. Hatta müteşabihatı anlaşılmasında zorluk bulunan ayetler olarak kabul etmemiz halinde de bu yorum isabetli olamaz. Zira insanları doğru yola sevk

18. İbn Teymiyye, el-Fetâva, XVII/419; Reşit Rıza, el-Menar, III/191.

19. Bkz. el-Fetâva, XVII/419.

20. Bkz. el-Itkân fi ulumi'l-Kur'an, Mustafa Diyb el-Buğa neşri, I baskı, 1987, Şam, I/640

21. et-Tabeñ, Camiï l Beyan, III/173; es-Suyutî, el-ltkân, I/640.

22. es-Suyutî, el-i̇tkân, I/641; İbn Teymiyye, el-Fetâva, XVII/386. 
etmek üzere gerekli olan prensipleri vazeden bir kitabı bu şekilde bir tasnife tâbi tutarak büyük bölümünü anlaşılmaz kılmak veya anlaşılması zordur demek uygun değildir.

7- İmam Ahmed ile Şafiîye nispet edilen bir görüşte ise; müteşabih, birkaç manaya gelebilen ayetlerdir. ${ }^{23}$

8- İmam Ahmed'den rivayet edilen ikinci bir görüşe göre ise müteşabih, açıklamaya ihtiyaç duyan ayetlerdir. ${ }^{24} \mathrm{Bu}$ görüş bir önceki görüşünün bir izahıdır.

9- Mücahid'e dayandırılan diğer bir görüşte ise müteşabih, manası birbirine benzeyen ayetlerdir. ${ }^{25}$

10- Abdurrahman b. Zeyd b. Esleme göre müteşabih, lafzı tekrar eden ayetlerdir. ${ }^{26}$

Görüldüğü gibi bu rivayetlerde aynı şahsa birden fazla görüş izafe edilmiştir. Bu son görüşler, müteşabih ayetlerin özelliklerini belirtmek için söylenmiş olup, sınırlama amacı taşımamaktadır.

11-Son dönemlerin âlimlerine nispet edilen bir görüşe göre ise müteşabih ayetler, Allah̀ in sıfatlarından bahseden ayetlerdir. ${ }^{27} \mathrm{Bu}$ konuya ileride temas edilecektir.

Bu görüşleri topluca tahlil ettiğimizde onlardan neticeleri itibarıyla şu iki sonucu çıkarabiliriz:

1- Muhkem manası kolaylıkla anlaşılabilen, müteşabih ise manasını sadece Allah` in bildiği ayetlerdir.

2- Muhkem, manası rahatlıkla anlaşılabilen, müteşabih ise manası kapalı olan ve anlaşılması için incelemeye, araştırmaya ihtiyaç duyulan ayetlerdir.

Başta Razî, İbn Teymiyye, son dönem âlimlerinden Reşit Rıza ve Ibn Âşur gibi âlimler olmak üzere çoğunluk bu görüştedir. İlk görüş ise daha çok Hanefî âlimlerine nispet edilmiştir. ${ }^{28}$

\section{Birinci Görüşün Değerlendirmesi}

Hanefî âlimlerine nispet edilen bu görüşle ikinci görüş arasında temelde bir tezat bulunmamaktadır. Íki görüş arasındaki ayrılık, kastedilen hususların farklılığından kaynaklanıyor. Bu görüşte olanların "Manasını sadece Allah

23. İbn Teymiyye, el-Fetâva, XVII/422.

24. A.g.e., aynı yer.

25. A.g.e., aynı yer.

26. A.g.e., aynı yer

27. A.g.e, 17/423.

28. ez-Zerkanî, Menahilï l-Irfan fî ulumi'l-Kur'an, Beyrut, 1988, II/272; İbn Âşur, et-Tahrir ve't-tenvir; III/156. 
bilir" dedikleri hususlar aslında ihtilaf konusu olan şeyler değildir. Mesela, Kıyamet'in vaktini elbette sadece Allah bilir. Aynı şekilde namazın rekatları, Deccal' in çıkışı vb. konular, insanlar tarafından bilinmeyebilir. Fakat bunların bilinip bilinmemesinin ayetlerin anlaşılmasıyla bir ilgisi yoktur. Bunlar, ayetlerin konusu değildir. Tartışma konusu olan ayetlerin manasının anlaşılıp anlaşılamayacağıdır. Kıyametin vaktini ise ayette Cenabı Allah, "Onun ilmi Allah`a aittir"29 diyerek kimsenin bilemeyeceğini belirtmiştir. Bunun manası da oldukça açıktır.

Müteşabihatı sadece Allah bilir diyenlerin tezlerine örnek verdikleri iki husus tartışmaya değer: Birincisi, bazı surelerin başında geçen hurufu mukattaalar, ikincisi ise Allah' in sıfatlarından bahseden ayetler.

$\mathrm{Bu}$ düşüncede olanlar, bazı surelerin başında geçen harflerin selef tarafından tefsir edilmemiş olmasını, manalarının anlaşılamamasıyla izah etmişlerdir. Ancak kanaatimizce onların tefsir edilmeyişleri, manalarının bilinmemesinden değil, bulunmamasından dolayıdır. Daha önce de işaret ettiğimiz gibi onlar tenbih edatlarıdır ve ilk muhataplar onları bu şekilde algılamışlardır. Selef âlimleri, Arap dili üslûbunda var olan bu metoda âşina olduklarndan herhangi bir eksiklik hissetmemiş, dolayısıyla bu tip harfler üzerinde konuşma ihtiyacı duymamışlardır. Bu konudaki tercihimiz budur. Ancak bazı âlimler onları tefsir etmeye de kalkışmışlardır. Suyutî "el-ìtkân" adlı eserinde ${ }^{30}$ bu görüşleri 10 grupta toplayarak zikretmiştir.

Sıfatlardan bahseden ayetlerde de bir anlam kapalılığı yoktur. İhtilafa sebep olan husus, Allah için Kur'an`da "Onun benzeri yoktur." denilmesidir. Allah hiçbir şeye benzemeyince O'na atfedilen sıfatların mahiyeti konusu zihinleri meşgul etmiştir. Kimi bu sıfatlan tevil etmiş, kimi de mahiyeti hakkında susmuştur. Yoksa ayetin metninin anlaşılması hususunda bir ihtilaf söz konusu değildir. Örneğin "Allah alimdir" denilince ayetin manası açıktır. Ancak "ilim" sıfatının mahiyeti tartışılmıştır. Bunun da metnin anlaşılmasıyla bir ilgisi yoktur, metin oldukça açıktır.

Âlimlerin bazılarını bu düşünceye sevk eden sebeplerden biri de Âli İmrân ayetinin metninin farklı yorumlanmaya müsait olmasıdır. Ayette:

"Fe emmellezîne fi qulûbihim zeyğun fe yettebiûne ma teşâbehe Minhu'btiğâel-fitneti vebtiğâe te'vîlihi vema ya'lemu te'vîlehu illallahu ve'r-rasihûne fíl-ilmi yeqûlûne âmennâ bihi....." denilmiştir. Müteşabihatın bilinemeyeceğini kabul edenler, vakfeyi ismi celal üzerinde düşündüklerinden bu neticeye varmışlardır. Buna göre müteşabihin manasını

29. A'raf suresi: 7/187; Ahzab suresi: $33 / 63$.

30. Bkz. 1. Cild, sayfa 658 ve sonras1. 
sadece Allah bilir. Vakfeden sonraki "vav" ise cümlenin cümleye atfı (yani ibtida) içindir. ${ }^{31}$

Bu görüş isabetli görünmemektedir. Zira eğer amaç sadece müteşabih ayetlere imanı belirtmek olsaydı buna sadece ilimde rasih olanlar tahsis edilmezdi. Çünkü bu ayetlere, yalnız âlimler değil tüm mü'minler inandık derler. Burada âlimlerin zikredilmesinden amaç onların müteşabih ayetleri bilebilecekleri fakat delaleti kat'i bir sonuca varamadıklan için onun kesin manasını Allah`a havale edeceklerini ifade etmektir. Buna benzer başka bir ayette şöyle buyrulmuştur:

"Onlardan ilimde rasih olanlar ve mü'minler sana ve senden önce indirilene inanırlar." 32 Eğer amaç sadece ayetlere imanı belirtmek olsaydı Âli Imrân ayetinde de şöyle denilebilirdi: İlimde rasih olanlar ve mü'minler ona inandik derler.

Müteşabihatın bilgisini Allah`a havale etmeye sebep teşkil eden diğer bir husus ise te'vil kelimesinin uğradığı anlam değişikliğidir. Te'vil, Kur'an'da lügat manası olan "bir şeyin varacağı netice" anlamında kullanılmıştır. Lisanu'l Arab'da: "el-Evlu: er-Rucû'. Âle'ş-şey'u, yeûlu evlen ve meâlen: Race'a"33 denilmektedir.

Bu kelime, Kur'an' da 7 surede geçmekte olup hepsinde de bu manada kullanılmıştır:

1 - Âli Imrân suresindeki bu ayette,

2- Nisa suresi 59. ayette: "Fein tenaze'tum fí sey'in feruddûhu ilallahi ve'r-resûli in kuntum tu'minûne billahi ve'l-yevmi'l-âhiri. Zâlike hayrun ve ahsenu te'vîlen."

Yani bu, netice olarak en hayırlı ve güzel olanıdır.

3- Araf suresi 52. ayette: "Velekad ci'nâhum bikitabin fassalnâhu alâ ilmin hüden ve rahmeten liqavmin yu'minûne. Hel yenzurûne illa te'vîlehu. Yevme ye'tî te'vîluhu yekûlu'l-lezîne nesûhu..."

Burada Te'vil, kitabın doğruluğu, dediklerinin neticesi anlamında kullanılmıştır.

31. Mưteşabihatın manasının bilinebileceğini kabul edenlere göre ise vakfe lafzatullah üzerinde değil, bir sonraki cümlede olacaktır. Buna göre "Yeqûlûne" lafzıyla başlayan cümle, ya ilimde rasih olanların hali veya gizli mübtedanın haberi olacaktır. Mana ise: "Müteşabih ayetlerin te'vilini Allah ve ilimde rasih olanlardan başkası bilemez. Onlar, ona inandık derler....." şeklinde olur. Ayetteki vakfe hakkındaki görüşler için bkz. İbn Kesir, Tefsiru'l-Kur'ani'l-azim, Mektebetu'l-Menar, 1. baskı, Ürdün, 1990, I/304-305, i'rab yapısıyla ilgili olarak bkz. es-Semîn el-Hâlebî, ed-Durru'l-masûn fi ulumi'l-kitabi'lmeknûn, thk, Ahmed el-Harrat, Daru'l-Kalem, 1. baskı, III/29.

32. Nisa suresi: $4 / 162$.

33. Bkz. İbn Manzur, Lisanü'l Arab, XI/32. 
4- Yunus suresi 39. ayette: "Bel kezzebû bimâ lem yuhîtû bi ilmihi velemmâ ye'tihim te'vîlüh." Burada da aynı anlamda kullanılmıştır.

5- Yusuf suresi

6. ayette: Ve yüallimuke min te'vîli'l-ehâdîs

36. ayette: Nebi'nâ bi te'vîlihi

44.ayette : Vemâ nahnu bi te'vîli'l-ehlâm bi âlimîn

45. ayette: Ene ünebbiukum bi te'vîlihi

100. ayette: Yâ ebeti hâzâ te'vîlu rü'yâye

101. ayette: Ve allemtenî min te'vîli'l-ehâdîs şeklinde geçmekte olup hepsinde dediğimiz anlamda kullanılmıştır.

6- İsra suresi 25. ayette: "Feevfu'l-keyle izâ kiltum vezinû bi'l-kıstasi'lmüstakîm. Zâlike hayrun ve ahsenu te'vîlen." Yine aynı manada verilmiştir.

7- Kehf suresi 78. ayette: "Seunebbiuke bi te'vîli mâ lem testeti' aleyhi sabren." Yani sabredemediğin işlerin neticesini sana bildireceğim.

Görüldüğü gibi te'vil kelimesi, Kur'an`da kesinlikle tefsir manasında değil, işin varacağı netice anlamında kullanılmıştır..$^{34}$

'Müteşabihin manasını kimse bilemez' dedikleri iddia edilen ilk dönem âlimleri, 'Kur'an’ın müteşabih ayetlerinin bahsettiği manaların kesin neticesini kimse bilemez' anlamında 'müteşabihin te'vilini sadece Allah bilir' demişlerdir. Sonralan bu kelime, tefsir manasında kavramlaşınca bu defa müteşabihatın tefsirini (yani manasını) kimse bilemez denilmeye başlanmıştır. ${ }^{35}$

\section{Tercihimiz}

Kur'an` in amacını, kelimelerin semantik yapısını ve Kur'an tefsirinin tarihini, yani vakıayı göz önünde bulundurduğumuzda ikinci görüşün daha isabetli olduğunu görürüz.

Kur'an, insanlan hidayete erdirmek, onlara nasıl yaşamalannın gerektiğini öğretmek amacıyla indirilmiştir. Bu da ancak onun anlaşılmasıyla mümkün olacaktır. Böyle bir amaçla indirilen Kur'an` in Hz. Peygamber dahil hiç kimse tarafından anlaşılamayan ayetlerinin bulunduğunu iddia etmek, bu amaca ters düşer. Bu iddiaya göre bu bölümlerin pratikte bir değeri kalmaz.

Muhkem ve müteşabih kelimelerinin semantik yapılan da böyle bir neticeye pek uygun düşmemektedir. Daha önce lügat manalarını verirken, muhkemin, istiâre ${ }^{36}$ yoluyla manası açık olan ayetlere delalet ettiğini

34. Bu konuyla ilgili geniş bilgi için bkz. Ibn Teymiyye, el-Fetâva, XVII/364.

35. Bkz.a.g.e., XVII/412.

36. Istiare, lafżn bilinen ve konuldugu manadan başka bir manaya nakledilmesidir. Bkz. Abbas, Fadl Hasan, el-Belağetu fununuha ve efnanuha, (IImül-beyan ve'l-bedi) Daru'l Furkan li'n-neşr ve't-tevzi', Amman, 1987, s. 157. 
söylemiştik. Ayeti kerimede müteşabih, muhkemin karşıtı olarak verilmiştir. O halde müteşabih de istiâre yoluyla manası kapalı olana ıtlak edilmiş olmalıdır.

Teşâbüh iki şey arasında olur. Bu da bize ayetin manasında birden fazla hususun anlaşllabileceği veya ayetin başka ayetlere benzediği gerçeğini verir. İşte şüphe edilen şey, bu birden fazla ortaya çıkan hususlardan hangisinin kastedildiğidir.

Tefsir tarihini incelediğimizde müteşabihin, pratikte "Allah'tan başka kimsenin bilemeyeceği ayetler" şeklinde değerlendirildiğini pek göremeyiz. Zerkeş̂’nnin de işaret ettiği gibi ${ }^{37}$ birinin bilemeyip Allah`a havale ettiği ayeti, bir başkası tefsir etmiştir. Bu konuda bir birlik sağlanamamıştır. Nelerin bilgisinin Allah`a ait olduğu hususunda bu tezi savunanlar dahi görüş birliği içerisinde olamamışlardır. İbn Teymiyye'nin de vurguladığı gibi bu konuda aşırı derecede ısrarlı davranan İbnu'l-Enbarî, müteşabih ayetler hakkında en çok konuşan kişidir; bu konudaki rivayetler genellikle meşhur tabii Katâde'ye dayandırılmaktadır, oysa onun kitabı bu müteşabih sayılan ayetlerin tefsiriyle doludur. ${ }^{38}$

Kur'an`ın tümünün anlaşılabilirliğini veya anlaşılmasının gerekliliğini destekleyen birçok delil ileri sürülebilir:

\section{Kur'an'dan}

1- "Sana herşeyi açıklayan kitabı indirdik".39 ayeti kerimesinde Kur'an'ın herşeye bir açıklama getirdiği belirtilmektedir. Anlaşılmayan taraflarının bulunduğunu iddia etmek onun bu vasfıyla çelişmektedir.

2- "Bu, ayetleri muhkem kılınmıs, sonra da uzun uzadıya açıklanmıs bir kitaptır."40 ayetinde onun, nazmıyla belağatıyla korunduğu ve ayetlerinin açıklandığı izah edilmektedir.

3- Kur'an, birçok ayetinde, ayetler üzerinde düşünülmesini istemektedir: "Kur'an`ı düşünmezler mi, Yoksa kalpleri kilitli midir?"41 "Kur'an`ı düşünmezler mi? Ĕger Allah'tan başkasından olsaydı onda bir sürü ihtilaf bulacaklardt."42 "Sözü düşünmezler mi, yoksa atalarına gelmeyen şeyler onlara mi geldi?" 43

37. Bkz. ez-Zerkeşî, el-Bürhân fì ulumi' l-Kur'an, Daru'l-Fikr, Beyrut, 1988. II/84.

38. Bkz. el-Fetâva, XVII/410-411.

39. Nahl suresi: $16 / 89$.

40. Hud suresi: 11/1.

41. Muhammed suresi: $47 / 24$.

42. Nisa suresi : $4 / 82$.

43. Mu'minûn suresi : $23 / 68$. 
Ayeti kerimeler; muhkem, müteşabih ayrımı yapmadan, Kur'an üzerinde düşünülmesini emrediyor. Eğer iddia edildiği gibi Kur'an`ın yapısı anlaşılamayacak cinsten olsaydı, tefekküre yapılan bu çağrı anlamsız olacaktı.

4- "Onlar ilmini kavrayamadikları ve henüz kendilerine yorumu da bildirilmemiş olan şeyi yalanladilar." 44 ayeti kerimesinde yalanlayıcılar bilmedikleri halde yalanladıklarından dolayı kınanmaktadırlar. Eğer bütün insanlar müteşabihatı bilmeme hususunda eşit olsayd, onların bu sebeple yerilmeleri anlamsız olurdu. O zaman onlar, sadece yalanladıkları için kınanmalıydı. Halbuki onlar bilemedikleri şeyleri yalanladıkları için kınanmışlardır. İşte Âli Imrân ayetinde de kalplerinde hastalık bulunanlar bu cehaletleri ve kötü niyetlerinden dolayı yerilmektedirler.

\section{Sünnetten ve Rivayetten}

1- Peygamberimiz (S.A.V)' in Ibn Abbas için "Allah`ım onu dinde fakih kıl ve ona te'vili öğret" 45 şeklindeki duası, ilimde rasih olanlann müteşabihatı bilebileceklerine delildir.

2- İbn Abbas`ın şu sözü: "Ben ilimde rasih olanlardanım ve onun te vilini bilirim." 46

3- Mücahidin şu sözü: "Mushaf, Fatihadan sonuna kadar İbn Abbas`a okudum ve her ayetini sorarak onun hakkında bilgi aldım."47

4- Ebû Abdurrahman es-Sülemî'nin şu sözü: "Osman, Abdullah bin Mesud ve başkaları gibi bize Kur'an`ı okutanlar, Hz. Peygamber'den okuyup ilmini öğrenmek için bir defada 10 ayetten fazlasını almadıklanını söylüyorlardı." 48 Onun bu sözünden sahabenin, aldıklan ayetler üzerinde düşündükleri, manalarını kavramaya çalıştıkları anlaşılmaktadır.

\section{Aklî Deliller}

1- Allah, insanlara uymalan için Kur'an`ı indirmiştir. Onlara anlayamayacakları şekilde hitap etmesi uygun değildir.

2- Müteşabihin manasını sadece Allah bilir dersek, Peygamberimizin kendisine indirilen kelamın manasını bilmediği neticesi ortaya çıkar. Buna göre Hz. Peygamber Allah'ın sifatlanndan, kaderden, ahiretten v.b. hususlardan bahsederken ne dediğini bilmeden konuşmuş oluyordu. Bu da

44. Yunus suresi: 10/39.

45. İmam Ahmed, el-Müsned, Müessesetu Kurtuba. trh. I/266, 314, 328, 335.

46. et-Taberî, Camiül-Beyan, III/183; ez-Zerkeşî, el-Bürhân fí ulumi'l-Kur'an, II/84.

47. Ibn Teymiyye, el-Felâva, XVII/395.

48. A.g.e. ayni yer. 
mantıksızlık olur. Zira konuşmaktan amaç mesaj vermek, anlaşmaktır. Anlam hasıl olmadan konuşmak, akıllı kişinin işi değildir.

\section{Farklı Bir İddia}

Burada Prof. Dr. Süleyman Ateş tarafından ileri sürülen farklı bir görüşe temas etmek kanımca faydalı olacaktır. Ateş, muhkem ve müteşabih kavramlanının söz konusu anlamıyla Kur'an`la ilgili olmadığını, burada bahsedilen 'Kitab' In Kur'an değil Tevrat olduğunu ileri sürmektedir:

"Kur'an-ı Kerim de özellikle "el-Kitab" şeklinde tarifli olarak antlan kitab, Kur'an değil, daha önce Musa'ya verilmiş olan Tevrat'tır. Cünkü Kur'an, kitab olarak indirilmemiştir... Âli İmrân suresinin 7. ayetinde Hz. Muhammed (S.A.V) e indirildiği bildirilen kitap, Hz. Musa'ya verilen kitabın, yani levhaların Arap̧̧a anlaınıdır."49

Hoca bunun gerekçesini ise şöyle açıklamaktadır:

"Zira o, Muhammed'e eski dili olan Ibranice ile vahyedilseydi Araplar anlayamaz, vahyin hikmeti gerçekleşmezdi."50

Sayın Ateş'e göre buradaki Kitap, Kur'an değil Tevrat olduğuna göre ayette zikri geçen müteşabih ayetler de Tevrat'ın ayetleridir. Kalplerinde hastalık bulunanlar ise Yahudîlerden onun ayetlerini kendi isteklerine uygun şekilde yorumlamaya çalışanlardır.

Kur'an'ı Tevrat'ın Arapça okuması olarak kabul etmek açık bir zorlamadır. Zira onlardan her biri farklı zamanlarda ve farklı toplumların yaşamlarını düzenlemek için indirilmiştir. Ikisinin de aynı kaynaktan olduğunu elbette kimse inkar edemez. Bunun tabiî neticesi olarak onlarda benzerlikler de olabilir. Zaten akidevî konular değişmez olduğuna göre bu konularda bir farklılık da beklenemez. Ancak her ikisinde de indikleri toplumun ihtiyaçlarına göre çözümler bulunduğuna göre hukukî bazı farklılıkların bulunması tabiidir. Zaten o da sonradan bu tezini farklı şekilde geliştirip her ikisinin öz itibarıyla bir olduğunu, Kur'an`da, Tevrat'ta bulunmayan şeylerin de bulunduğunu söylemiştir. ${ }^{51} \mathrm{Bu}$ durumda onu, Tevrat'ın Arapça okuması kabul etmek mümkün değildir. Hocanın gerekçesine de katılmamız mümkün değildir. Zira Arap toplumunun dışındaki milletler, mesela Türkler için böyle bir gerekçe (yani Kur'an`ın kendi dillerinde olmayışı) hâlâ geçerlidir. Bu gerekçe sanki Kur'an bölgesel bir kitapmış fikrini ima etmektedir.

"Kitab"ın lam's tarifli geldiğinde Tevrat’a işaret ettiğine de katılmıyoruz. Zira Âli İmrân suresinin hemen başında: "Nezzele aleyke'l-

49. Tefsirin Dünü ve Bugünü Sempozyumu (22-23 Ekim 1992), Samsun, 1992, s. 6.

50. A.g.e., s. 7.

51. A.g.e., s. 10. 
kitabe bi'l-hakki musaddiken limâ beyne yedeyhi ve enzele't-Tevrâte ve'lIncîle min kablu huden li'n-nasi ve enzele'l-furkan" buyurulmuştur. Ayette, Kur'an, Tevrat, İncil ve Furkan'ın her birisi ayrı ayrı zikredilmiştir. Eğer buradaki "el-Kitap"tan kasıt Tevrat olsaydı, Tevrat, tekrar zikredilmezdi. Yine Mâide suresi 48. ayette: "Ve enzelnâ ileyke'l-kitâbe bi'l-hakki musaddiken limâ beyne yedeyhi mine'l-kitabi ve muheyminen aleyhi" denilmiştir. Görüldüğü gibi ayette 'kendisinden önceki kitabı doğrulayıcı olarak sana kitabı indirdik' denilmiştir. Bu ayette 'kitab' kelimelerinin ikisi de harf-i tarifli olarak gelmiştir.

Bunun misallerini çoğaltmak mümkündür. Ancak buna gerek duyulmadan açıkça görülüyor ki "el-Kitab" kelimesi harf-i tarifli olarak hem Kur'an için hem Tevrat ve hem de İncil için kullanılmıştır. Yahudî ve Hristiyanlara da bundan dolayı 'Ehl-i Kitab' denilmiştir.

Sayın Ateş'e bu düşüncesinde temel teşkil eden bir husus da Âli İmrân suresinin ilk 80 ayetlik bölümünün Necran heyetinin $\mathrm{Hz}$. Peygamberle giriştikleri münâzara üzerine indirilmiş olduğunun rivayetlerde geçmesidir. Hoca, bunu göz önünde bulundurarak, burada anlatılan şeylerin Tevrat'la ilgili olduğunu iddia etmektedir..$^{52}$ Burada da gözden kaçan bir husus vardır. Rivayetlere göre Necran heyeti kendi kitaplarındaki ayetlerle değil, Kur'an`da geçen "İnnâ", "Nahnu", "Ruhun Minhu", "Kelimetullahi" gibi lafızları ileri sürerek, İsa'nın ilahlığını tartışmışlardır. ${ }^{53}$ Sure, onların tartışmaları üzerine inmiş olsa da Kur'an` dan bahsetmektedir. Buradaki hitap, onları kapsadığı gibi herkese şâmildir. Zira itibar sebebin hususiliğine değil lafzın umumîliğinedir.

\section{Müteşabih Ayetlerin Bulunmasının Hikmeti}

Müteşabihatı, "Kesin manasının anlaşılmasında zorluk bulunan ayetler" olarak kabul ettiğimize göre bu zorluğun hikmetini de izah etmemiz gerekiyor.

Âlimler bu konuda birçok sebep ileri sürmüşlerdir. Müfessir Razî tefsirinde bu görüşleri 5 madde halinde aktarmaktadır ${ }^{54}$ Ancak kanaatimizce bunların çoğu müteşabihatın hikmeti olmaktan çok uzaktır. Mesela bunlardan birisinde teşabühün hikmeti olarak, 'bu tip ayetlerin mezheplere uygun düşmeleri' denilmiştir. Bunu müteşabihin hikmeti olarak kabul etmek nasıl mümkün olur? Kur'an inerken mezhepler mi vardı?ss Bize

52. A.g.e., s. 19.

53. Bkz. İbn Teymiyye, el-Fetâva, XVII/377-378.

54. Bkz. Tefsirü'r-Razî, İstanbul. trh. II/598.

55. Bkz. el-Menar, 1ll/170. 
göre müteşabih ayetlerin bulunmasının hikmetleri olarak şunlar zikredilebilir:

1- Kur'an`da manası kapalı ayetlerin bulunması, insanı, onlar üzerinde düşünmeye, aklını kullanmaya sevk eder. Kur'an, insana bir nimet olarak verilen aklın kullanımını sıkça tembihlemiştir. "Düşünmezler mi?" "Akletmezler mi?" gibi ibareler Kur'an` da sık sık rastladığımız ibarelerdir.

2- Kur'an, evrensel ve ebedî bir kitaptır. O, her devirde insanların ihtiyaçlarına cevap verebilecek bir özelliğe sahiptir. Teşabühü, ayetin manasının kapalı olması şeklinde değerlendirirsek, onun yoruma açık bir tarafı bulunur. Insanlar her devirde onun üzerinde düşünme ve yorum yapma imkanına sahip olur. Kimse nihaî noktayı koyma yetkisine sahip olamaz.

3- Allah bu ayetlerle insanları bir imtihana tâbi tutmuştur. Nitekim ayette kalplerinde hastalık bulunanların bu kapalılık bahanesiyle fitneye bulaştıkları ifade edilmiştir. Illimde rasih olanlar ise herhangi bir şüpheye düşmezler.

\section{Teşabüh e Sebep Olan Durumlar}

Ayetlerdeki teşabüh izafî olup, muhatabın kültürel durumuna göre farklılık arzetmektedir. Müfessir İbn Âşur "et-Tahrir ve't-tenvir" isimli tefsirinde bu sebepleri şöyle sıralamıştır: 56

1- Kur'an da verilmesi istenilen, ancak insanlarm onlan tam idrak etme kabiliyetine sahip olmamalarından dolayı icmalen verilen hususlar. Kıyametin halleri, ru'yet ve Rububiyetle ilgili bazı hususlardan bahseden ayetler gibi.

2- Dil' in, manasını tam olarak ifade etmekte yetersiz kaldığı yüksek manaların, insanların anlayabileceği tarzda verilmesi. Allah`ın Rahman, Rauf, Mütekebbir, Yerin ve Semavatın Nuru gibi sıfatları bu kategoride değerlendirilebilir.

3- Çağların ilmî gelişimlerine göre insanların ayetleri anlamadaki farklılıkları. İlmî seviye geliştikçe Kur'an'daki ilmî ayetler de ona paralel olarak anlama kolaylığı arzedecektir. Bu hususa şu ayetleri misal verebiliriz:

"Ve'ş-şemsu tecrî li mustekarrin lehâ" (Yasin: 36/38).

"Ve erselne'r-riyâha levâkiha" (Hicr:15/22).

"Yukevviru'l-leyle ale'n-nehâr" (Zümer:39/5).

4- Arap dilinde kullanılan mecâz, kinâye vb. hususlar da zaman zaman anlama güçlülüğüne sebebiyet vermiştir. Zira bu şekilde geçen bazı durumlar zahiren İlahî mahiyetle çelişir gibi görünmektedir. Bu da âlimleri onlan

56. Bkz. III. Cilt, sayfa 158 ve sonrası (özetle). 
yorumlama hususunda tevakkuf a sevk etmiştir. Buna da şu ayetleri misal verebiliriz:

"Fe inneke bi a'yunina" (Tur:52/48).

"Ve's-semâe beneynâhâ bi eydin" (Zariyat: 51/47).

"Ve yebkâ vechu rabbik" (Rahman:55/27).

5- Kur'an` in indirildiği dönemde çok yaygın olmayan bazı lafızlar:

"Fakiheten ve ebben" (Abese:80/31).

"Ev ye'huzehum ala tehavvuf" (Nahl:16/47).

"Inne Ibrahime le evvahun halîm" (Tevbe: 9/114) gibi lafızlar bazı sahabîler tarafından anlaşılamamıştır.

6- Arapların, Teyemmüm, Zekat ve Riba ${ }^{57}$ gibi mahiyetini tam olarak bilemedikleri bazı şer'î kavramlar.

7- Arap dili üslûbunda olup, insanların fark edemediği bazı haller de bazen anlama güçlülüğüne sebep olmuştur. "Leyse kemislihi şey'un" (Şura: 42/11) ibaresindeki "Kâf"ı ziyadeliği, "Yuhadiûnellahe ve huve hadiuhum" (Nisa: 4/142) ibaresindeki müşâkele ${ }^{58}$ gibi. Bunu fark edemeyenler "aldatma" fiilinin Allah`a nispet edilmesini uygun görmemişlerdir.

8- Araplar arasında yaygın olan bazı âdetlere işareten inen ayetler bu âdetlerin unutulmasıyla anlaşılmaz hale gelmiştir. Mesela: "İyi davranış, asla evlere arkalarından gelip girmeniz değildir." (Bakara:2/189) ayeti Kur'an` ın indiği dönemde yaygın olan bir âdeti dile getirmektedir. Sonraki dönemlerde âlimler bunu anlamakta zorluk çekmişlerdir.

9- Son olarak anlayışı kıt bazı şahıs ve fırkalar anlamadıkları veya kendilerine ters düşen ayetleri Müteşabih deyip geçiştirmişlerdir. Bu duruma misal olarak da Cebrîlerin, "Kur'an't anlamalarına engel olmak için kalplerinin üstüne perdeler verdik." (Enam: 6/25) ayetini kendilerine uygun tefsir etmeleri, diğer ayetleri müteşabih saymaları gösterilebilir. ${ }^{59}$

\section{Sonuç}

Görüldüğui kadarıyla bu konudaki ihtilaf, öze taalluk eden bir ihtilaf olmayıp, şeklîdir. Zira bu konudaki tartışmaların dayanağı -bir çok meselede

57. İbn Âşur bu tabirlerin başlangıçta meşhur olmadıklarını, sonradan bilinen ıstılah manalarıyla yaygınlaştıklarını söylemekte ve buna misal olarak Hz. Ömer' in "Riba"yı bilmediğini vermektedir. Bkz. III/159.

58. Müşakele: Bir önceki kelimeye benzerlik olması amacıyla bir kelimenin manasının dışında, başka bir mana için kullanılmasıdır. Bkz. Abbas, Fadl Hasan, el-Belağetü fünûnuha ve efnânüha (Ilmu'T-beyan ve'l-bedî'), s. 294.

59. Bu konuda daha geniş bilgi için bkz. Tefsirü'r-Razi, III/598. 
olduğu gibi- sıfatlar ve gaybî konuların mahiyeti hakkındaki fikir ayrılıklarıdır. Allah'a el, kol, yüz vb. uzuvların isnad edilmesini uygun görmeyen başta Mu'tezile ve Cebn̂ler olmak üzere çeşitli fırkalar, Kur'an'da geçen bazı ayetlerin zahiren bu düşünceleriyle çeliştiğini görünce ya bu ayetlerin muradının bilinemeyeceğini iddia etmişlerdir veya onlanı te'vile girişmişlerdir. Bu durum, zamanla bu tip ayetlerin manasının bilinip bilinemeyeceği tartışmalarını doğurmuştur. Başta İbn Teymiyye olmak üzere 60 Kur'an ayetlerinin $\mathrm{Hz}$. Peygamber tarafından açıklandığını savunan âlimler ise bu yaklaşımlarının tabiû bir sonucu olarak Kur'an'ın bütün ayetlerinin anlaşılmasının gerekliliğini savunmuşlardır. Bu iki anlayış arasındaki polemik, muhkem müteşabih konusundaki tartışmalara daha da hız kazandırmıştır.

$\mathrm{Bu}$ konudaki tartışmaların bir başka sebebi ise, te'vil kelimesinin geçirmiş olduğu anlam kaymasından doğan yanlış anlamalardır. Aslında "işin varacağı netice" anlamında olan bu kelime, zamanla tefsir manasında kavramlaşınca bu defa 'bu ayetlerin tefsirini (manasını) Allah'tan başka kimse bilemez' denilmeye başlanmıştır. Geçmişte yapılan ve bazılarınca "Kur'an in bazı bölümlerini hiç kimse anlayamaz" teziyle neticelenen münakaşalar, te'vil kavramının geçirdiği bu anlam değişikliği ve yanlış anlaşılmalardan kaynaklanmış olup, Kur'an’ın anlaşılmassına katkı sağlaması gerekirken zaman zaman bir engel teşkil etmiştir. Kur'an ın anlaşılması, onu "anlaşılamaz" kılmakla asla gerçekleşemez. Anlaşılamaz diye verilen hususlar iyice incelenince anlaşılır oldukları ortaya çıkacaktır. Kur'an`ın anlaşılması için üzerinde düşünmeye, incelemeye yönelik bu çağnı bizzat Kur'an` ın çağrısıdır.

Teşabüh (anlam kapalılığı) Kur'an`ın aslından kaynaklanan bir olgu olmayıp, insanların bilgi durumuna izafeten meydana gelen bir husustur. İnsanlar bilgi ve yetenekleri oranında bu tip ayetleri anlayabilirler. Bu husus, Kur'an'ın evrenselliği ve ebedîliği ilkelerine anlam katmaktadır. Kur'an, insanlan hidayete erdirmek, onlara nasıl yaşamalarının gerektiğini öğretmek amacıyla indirilmiştir. Müteşabih ayetleri; değişen zaman ve mekan şartlarına göre farklı yorumlanabilecek ayetler olarak kabul ederek, Kur'an'ı bütün toplumları ve olayları kucaklayacak ilkeler olarak anlamak Kur'an'ın felsefesine ve insanlığa getirdiği mesaja daha uygun olur. İşte bu tip ayetleri, ilimde rasih olan âlimler de anlayabilirler. Kur'an'ın anlaşılamaz taraflarının bulunduğu iddiası bu misyonunu zedeleyecektir.

60. Ibn Teymiyye'nin bu konudaki düşünceleri için bkz. Arpa, Enver, Ibn Teymiyye'nin Kur'an Anlayışı ve Anlama Metodu, Fecr Yayınevi, Ankara 2002, s. 76. 


\section{KAYNAKÇA}

ABBAS, Fadl Hasan, cl-Belağetü fünûnuha ve efnânüha (İlmu'l-beyan ve'l-bedî’) Daru'lFurkan, 1.baskı, Amman, 1987.

AHMED b. Hanbel, el-Müsned, Mücssesetu Kurtûba, tarihsiz.

ARPA, Enver, Ibn Teymiyye'nin Kur'an Anlayış ve Anlama Metodu, Fecr Yayınevi, 1. baskı, Ankara, 2002.

BEYDAVÎ, Envaru't-tenzil ve esraru't-te'vil, Daru'l-Fikr, tarihsiz.

CEVHERÎ, İsmail bin Hammad, es-Sihah tâcü'l-lüğeti ve sihahu'l Arabiyye, Ahmed Abdullyafur neşri, Misır.

IBN ÂŞUR, Tahir bin Muhammed el-Cezaiñ, et-Tahrir ve't tenvir, Tunus. tarihsiz

IBN KESIR, Tefsiru'l-Kur'ani'l-azim, Mektebetu'l-Menar, 1. baskı, Ürdün, 1990.

IBN MANZUR, Cemalettin Muhammed bin Mukrim, Lisanül Arab, 1956, Beyrut.

IBN TEYMIYYE. Takiyuddin Ahmed, Mecomun̂ fetava li şeyhil İslam Almed b. Teymiyye,

Daru Alemi'l Kutub, Riyad, 1991.

er-RAZî, Fahrettin, Tefsiru'r-Razî (Mefâtihu'l-gayb), İstanbul, tarihsiz.

REŞiT RIZA, Muhammed, Tefsiru'l-Kur'ani'l-hakim (el-Menar) Menar matbaası, Mısır, tarihsiz.

es-SEMİN cl-Hâlebî, ed-Durru'l-masûn fî ulumi'l-kitabi'l-meknûn, thk, Ahmed el-Harrat, Daru'l-Kalem, 1. baskı, tarihsiz.

es-SUYUTî, Celalettin Abdurrahman, el-ittkân fi uluıni'l Kur'an, Mustafa Diyb el-Buğa neşri, 1. baskı, Şam, 1987.

et-TABERÎ, Muhammed bin Cerir, Camiu'l-beyan an te'vîli ayi'l-Kur'an, 2. baskı, Mısır, 1954.

Tefsirin Dünü ve Bugünü Sempozyumu, (22-23 Ekim 1992) Samsun, 1992.

ez-ZEMAHŞERÎ, Mahmud b. Amr, el-Keşsaf an hakaiki't-tenz'îl ve uyuni'l-akavil fí vucuhi't-te'vil, Dan'l-Fikr, l.baskı, 1977.

ez-ZERKÂNî, Muhammed Abdülazîm, Menahilu'l irfan fî ulumi'l-Kur'an, Beyrut, 1988.

cz-ZERKEŞî, Bedruddin Muhammed b. Abdullah, el-Burhân fì ulumi'l-Kur'an, Daru'l-Fikr, Beyrut, 1988. 